\title{
Aoridae (Amphipoda: Corophioidea) from the Austral Isles
}

\author{
ALAN A. MYERS \\ Department of Zoology and Animal Ecology, \\ University of Ireland Cork, Lee Maltings, Prospect Row, Cork, Ireland. \\ alanmyers@crustacea.net
}

\begin{abstract}
Six species of aorid amphipod are recorded from the Austral Isles. Two new species are described and figured.
\end{abstract}

Myers, Alan A., 2005. Aoridae (Amphipoda: Corophioidea) from the Austral Isles. Records of the Australian Museum 57(3): 355-360.

Six species of aorid amphipod were collected in 0-3 m depth in the Austral Isles by J.K.Lowry and J.M. Poupin during August, 1991. Two species, Bemlos callistemon n.sp. and Globosolembos rimatara n.sp. are new to science and one species Aoroides vitiosus Myers was previously known only from Papua New Guinea. The remaining three species are known to be widespread in the western Pacific. The new species are described and figured.

Abbreviations used in figures. $G$, gnathopod; $L$, labium; $M d$, mandible; $M x$, maxilla; $P$, pereon (sternal spines); $U$, uropod; $x$, palm.

\section{Aoroides Walker}

Aoroides vitiosus Myers, 1995

Aoroides vitiosus Myers, 1995: 27-30, figs. 1-2.

Material examined. AM P54524 $\left(10^{\star}, 11+q\right.$ q ) lagoon in front of Puatai Rock, Avera, Rurutu, Austral Isles, $1 \mathrm{~m}$, rubble and algae inside reef platform, 10 August 1991, J.K. Lowry; AM

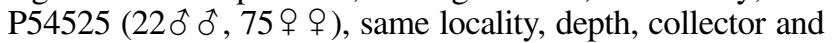
date, Sargassum-like alga from inner reef platform.

Remarks. In present material, the male gnathopod 2 has a normal merus with the distal margin oblique. In material from Papua New Guinea, the anterodistal margin of the merus of gnathopod 2 is extended so that the distal margin becomes transverse. This character state, together with a somewhat more elongate and slender merus on the male gnathopod 1, appears to be the only significant difference between present material and that from the type locality. For the present, the two materials are considered as conspecific.

Habitat. Amongst algae (Austral Isles) and sea grasses (Papua New Guinea) in shallow water.

Distribution. Papua New Guinea and the Austral Isles.

\section{Bemlos Shoemaker \\ Bemlos callistemon n.sp.}

Figs. 1-2

Material examined. HolOTYPE AM P47081 $\delta^{\star} .4 .8 \mathrm{~mm}$. Reef platform in front of Mataura, Tubuai, Austral Isles, $1.5 \mathrm{~m}$ depth, calcareous and, bottle-brush red algae on coral outcrops, J.K. Lowry, 12 August 1991. PARATYPES AM P47081 (1 $0^{\star}, 3$ ㅇ + ), same locality, habitat, collector and date, $0.5-2.0 \mathrm{~m}$ depth.

Description. Male. Head lateral cephalic lobes apically rounded; eyes clear (in alcohol), with a dark central core. Pereon with sternal spines on segments 1-3. Head 


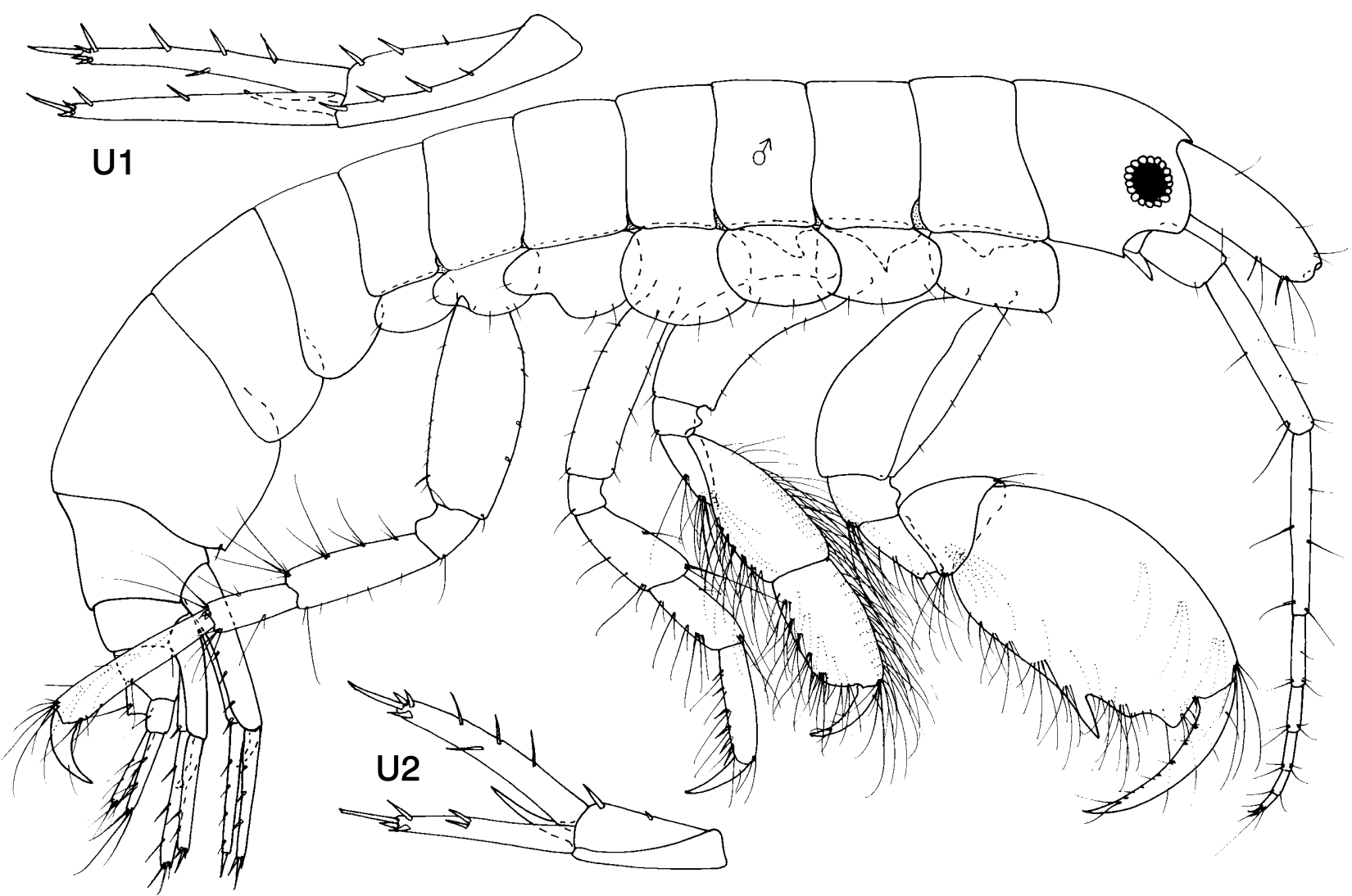

Fig. 1. Bemlos callistemon n.sp., Tubuai, Austral Isles. male paratype.

anteroventral margin moderately excavate, moderately recessed. Antenna 1 unknown. Antenna 2 slender, poorly setiferous; peduncular articles 4 and 5 subequal in length; flagellum with 6 articles, the terminal article rudimentary. Mandible palp article $360 \%$ longer than article 2, posterior margin straight, with setae of two distinct lengths. Maxilla 1 inner plate with one long pectinate apical seta. Labium outer plate with long mandibular processes and with both fine and stout distal setae. Maxilliped palp without winglike flanges. Gnathopod 1 coxa subrectangular, unproduced, a little less than twice as long as broad; carpus short, cupshaped; propodus more than three times length of carpus, palm short almost transverse, posterodistal margin sinuous, delimited from posteroproximal margin by a strong acute spine, resulting in a deep V-shaped incision; dactylus elongate, greatly overlapping palm. Gnathopod 2 basis stout, anterior margin concave carpus about $20 \%$ longer than propodus; carpus and propodus slender, anterior margins densely clothed in long setae; dactylus overlapping palm. Pereopods 3-4 propodus posterior margin with about six strong, evenly spaced robust setae. Epimeron 3 posterodistal margin with small spine above notch bearing a small seta. Uropod 1 peduncle subequal in length with rami, interramal spine more than one third length of peduncle. Uropod 2 peduncle interramal spine well developed, two thirds length of peduncle; inner ramus almost one and one half times length of peduncle. Uropod 3 inner ramus longer than outer; and more than twice length of peduncle, outer ramus with small second article. Telson with fine setae only.

Female dimorphic characters: Gnathopod 1 coxa one and one half times as long as broad; propodus palm not excavate, defined by a small obtuse process.
Remarks. This species is superficially similar to Bemlos dolichomanus from Australia (Bass Strait) but differs from that species in the broad and anteriorly concave basis and heavily setose carpus and propodus of the male gnathopod 2 , in the more slender uropods $1-2$, the longer mandible palp article 3 , and the different configuration of the male gnathopod 1 palm.

Habitat. Red algae over coral sand.

Distribution. Known only from the type locality.

Etymology. From the plant genus Callistemon (Myrtaceae), in reference to the bottle-brush-like nature of the red alga from which the holotype was collected.

\section{Bemlos dentischium taparum (Myers, 1985)}

Lembos dentischium taparum Myers, 1985b: 369-373, figs. 236237.

Bemlos dentischium taparum.-Myers, 1990:157; Myers, 1997: 108.

Material examined. AM P47080 AM (2 $\widehat{0} \hat{o})$. Reef platform in front of Mataura, Tubuai, Austral Isles, $2 \mathrm{~m}$, calcareous and bottle-brush red alga on coral outcrops, J.K.

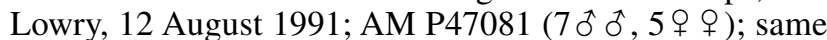
locality, habitat, collector and date, $1.5 \mathrm{~m}, \mathrm{AM}$ P54527 (1 $\sigma^{\widehat{0}}$, 1 ㅇ, 3 immatures); same locality, collector and date, $0.5 \mathrm{~m}$, brown algae on sides of old bommies; AM P54528 (1 $1 \hat{\text {, }}$ $3 ㅇ ㅜ$ ). Near edge of lagoon at Rairua, Raivavae, Austral Isles, $3 \mathrm{~m}$, mixed red algae from inner reef front, J.K. Lowry, 14 August 1991; AM P54529 (6 $0 \widehat{o}$, 12 우 우, 20 immatures); same locality, collector and date, $1 \mathrm{~m}$, rubble and sand; AM P54532 (1 0 , 3 q,+ 2 immatures). Point Maomao, Ha'urei Bay, Rapa, Austral Isles, 2 m, loose coral rubble, J.K. Lowry, 17 August 1991; AM P54531 (5 ㅇ $q$ ) near edge of lagoon at Rairua, Raivavae, Austral Isles, 0.5-1 m depth, coarse 


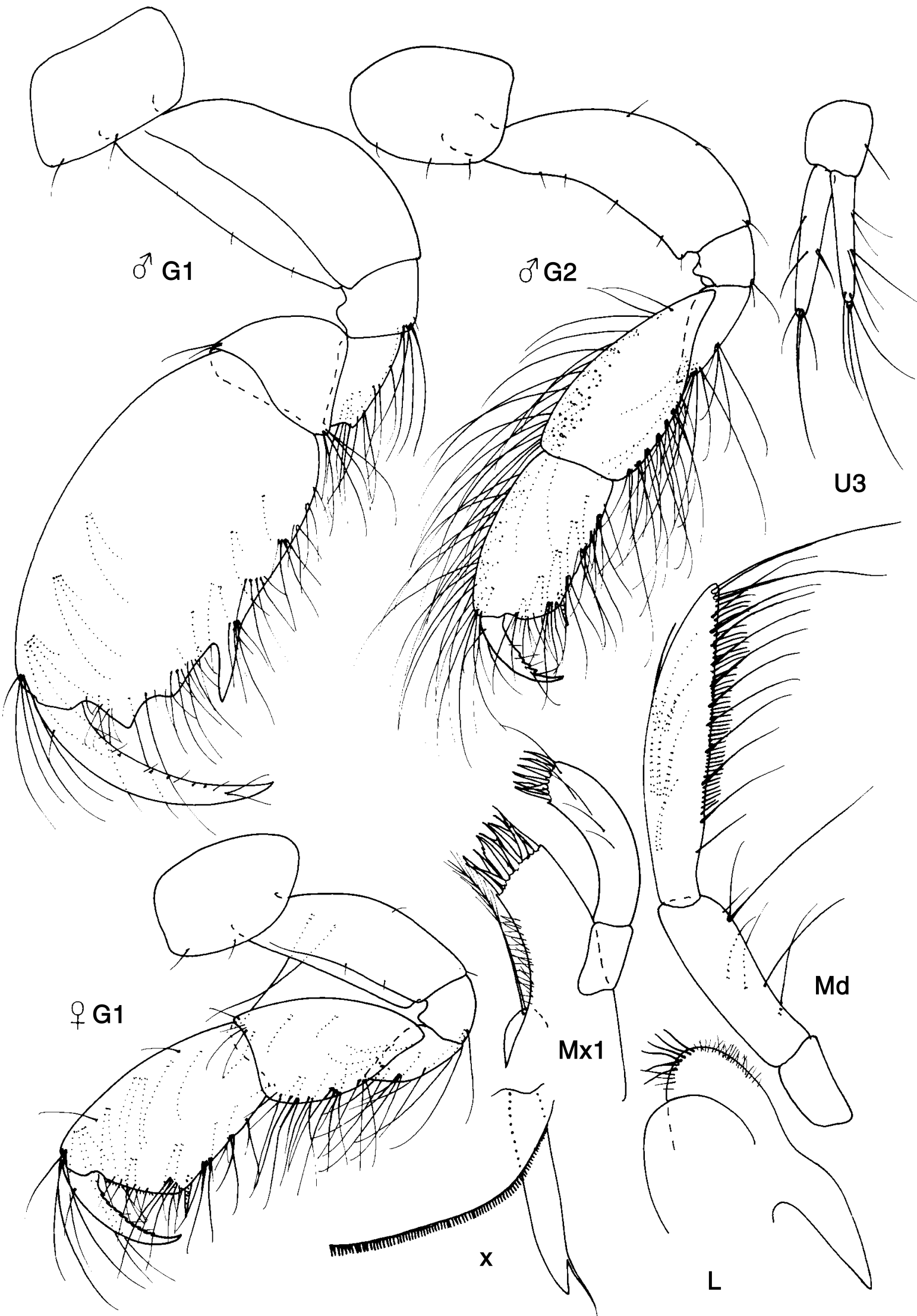

Fig. 2. Bemlos callistemon n.sp., Tubuai, Austral Isles. male paratype; female paratype gnathopod 1.

sand and rubble, J.K. Lowry, 14 August 1991; AM P54533 $\left(20^{t}, 4\right.$ 우 9 ), same locality, depth, collector and date, in rubble and sand; AM P54534 (10, 3 우, 3 immatures), same locality, collector and date, $0.5 \mathrm{~m}$, small black sponge.
Remarks. Myers (1985b) described the subspecies Bemlos dentischium taparum on the basis of its pigmentation pattern. This small difference was justified by the fact that the nominate form was known only from Florida and the 
Bahamas. Present material agrees well with the description of this subspecies from Tonga, Western Samoa and the Cook Islands.

Habitat. Shallow water $(0-3 \mathrm{~m})$ amongst algae and coral rubble.

Distribution. Cook Islands, Western Samoa, Tonga, Austral Isles.

\section{Bemlos tui (Myers, 1995)}

Lembos tui Myers, 1985b, 398, figs. 255-258.

Bemlos tui.-Myers, 1995, 30, fig. 3; Myers, 1997: 108; Myers, 1998: 193, fig. 5b.

Material examined. AM P47079 $(4 \hat{\jmath} \widehat{\phi}, 9$ 우). Lagoon in front of Puatai Rock, Avera, Rurutu, Austral Isles, $0.5 \mathrm{~m}$, algae and mussels on shallow reef platform, 10 August 1991, J.K. Lowry; AM P54524 (6 0 o 0 , 6 ㅇ 9,2 immatures), same locality, collector and date, $1 \mathrm{~m}$, rubble and algae inside

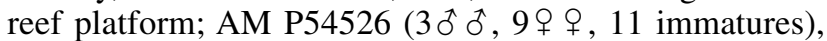
same locality, depth, collector and date, Sargassum-like alga

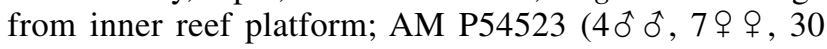
immatures). Small lagoon near Mutua Ura, Rimatara, Austral Isles, $1.5 \mathrm{~m}$ depth, coarse sand, 9 August 1991, J.K. Lowry \& J.M. Poupin.

Habitat. In areas with low water movement and of consequence high silt levels, in algae, coral rubble, mussels.

Distribution. Papua New Guinea, New Caledonia, Western Samoa, Austral Isles.

\section{Globosolembos Myers}

\section{Globosolembos excavatus (Myers)}

Lembos excavatus Myers, 1975: 32, figs. 76-82; Ledoyer, 1982: 218, figs. 104-105 (in part).

Lembos processifer.-Ledoyer, 1984: 35 (in part), fig. 16 ("forme 2") (not L. processifer Pirlot, 1938: 330, figs. 147-149).

Lembos (Globosolembos) excavatus.-Myers, 1985a: 363, fig. 234.

Globosolembos excavatus.-Myers, 1986: 285, figs. 11-12; Myers, 1988: 329; Myers, 1998: 195.

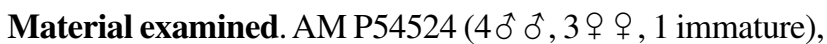
lagoon in front of Puatai Rock, Avera, Rurutu, Austral Isles, 1 $m$ depth, rubble and algae inside reef platform, J.K. Lowry, 10 August, 1991; AM P47079 (1 9 ) same locality, collector and date, $0.5 \mathrm{~m}$, sand, algae and mussels on shallow reef platform; AM P54531 (1 $\hat{0}, 5$ ㅇ $\uparrow, 2$ immatures) near edge of lagoon at Rairua, Raivavae, Austral Isles, 0.5-1 m depth, coarse sand and rubble, J.K. Lowry, 14 August 1991.

Remarks. Specimens from the Austral Isles closely resemble those collected in Tonga (Myers, 1986).

Habitat. In sand and rubble, often in association with algae and phanerogammes.

Distribution. East Africa, Madagascar, north eastern Australia, New Caledonia, Tonga, Austral Isles.

\section{Globosolembos rimatara n.sp.}

Figs. 3-4

Material examined. HOLOTYPE AM P54523 $\widehat{\jmath} .4 .2 \mathrm{~mm}$. Small lagoon near Mutua Ura, Rimatara, Austral Isles, $1.5 \mathrm{~m}$ depth, coarse sand, J.K. Lowry \& J.M. Poupin, 9 August 1991. PARATYPES, AM P54523, (2 $\widehat{\delta} \hat{\sigma}, 1$ + ), same data as holotype.

Other material. AM P54530 ( $7 \hat{\delta} \delta, 11$ $ᄋ$ $)$, near edge of lagoon at Rairua, Raivavae, Austral Isles, $1 \mathrm{~m}$, rubble and sand, 14 August 1991, J.K. Lowry; AM P54533 (10 §ิ ô, 9 우, 1 immature) Point Maomao, Ha'urei Bay, Rapa, Austral Isles, 0.5-2 m depth, rubble and sand, 17 August

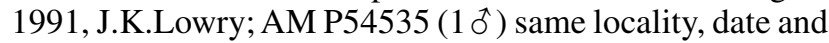
collector, no depth or substrate given.

Description. Male. Head lateral cephalic lobes apically truncate; eyes clear (in alcohol). Head anteroventral margin moderately excavate, moderately recessed. Body with sternal spines on pereon segments $1-5$. Antenna 1 and 2 unknown. Mandible palp article $310 \%$ longer than article 2 , weakly falcate, setae of variable lengths. Maxilla 1 inner plate with one long pectinate apical seta. Labium outer plate with long mandibular processes and with both fine and stout distal setae. Maxilliped palp without wing-like flanges. Gnathopod 1 coxa twice as long as broad; propodus one and one half times length of carpus, palm excavate, the excavation broad, shallow and terminating proximally in a subacute spine; dactylus elongate, greatly overlapping palm. Gnathopod 2 basis stout, anterior margin with a few long setae; carpus subequal in length with propodus; carpus and propodus anterior margins densely clothed in long setae; dactylus slender, fitting palm. Pereopod 6 basis with long setae on both anterior and posterior margins. Pereopod 7 unknown. Epimeron 3 rounded. Uropod 1 peduncle about $20 \%$ longer than rami, interramal spine about one quarter length of peduncle. Uropod 2 peduncle interramal spine absent; peduncle and rami subequal. Uropod 3 rami subequal; inner ramus subequal with peduncle. Telson with fine setae only.

Female dimorphic characters:. Gnathopod 1 coxa one and one half times as long as broad; propodus palm not excavate, defined by a small obtuse process.

Remarks. In having a deeply excavate palm on the male gnathopod 1, G. rimatara resembles G. excavatus (Myers) (also known from the Austral Isles), G. indicus (Ledoyer) and G. lunatus Myers, but in those species, the excavation does not terminate proximally in a subacute process. In addition, G. excavatus differs from the present species in having mandible palp article 3 long (about 140\% length of article 2), male gnathopod 2 propodus elongate, pereopod 6 basis with setae on posterior margin only, uropod 1 interramal spine one third length of peduncle, uropod 3 inner ramus significantly longer than outer and uropod 3 rami one and one half times length of peduncle. Globosolembos rimatara differs from both G. indicus and G. lunatus in the absence of an interramal spine on the peduncle of uropod 2. It also differs from $G$. indicus in the non-falcate mandible palp article 3, and from G. lunatus in the weakly spinose uropods $1-2$ and the non-sinuous palm of the female gnathopod 1 .

Habitat. In sand and rubble.

Distribution. Known only from the Austral Isles.

Etymology. Named after the type locality. 


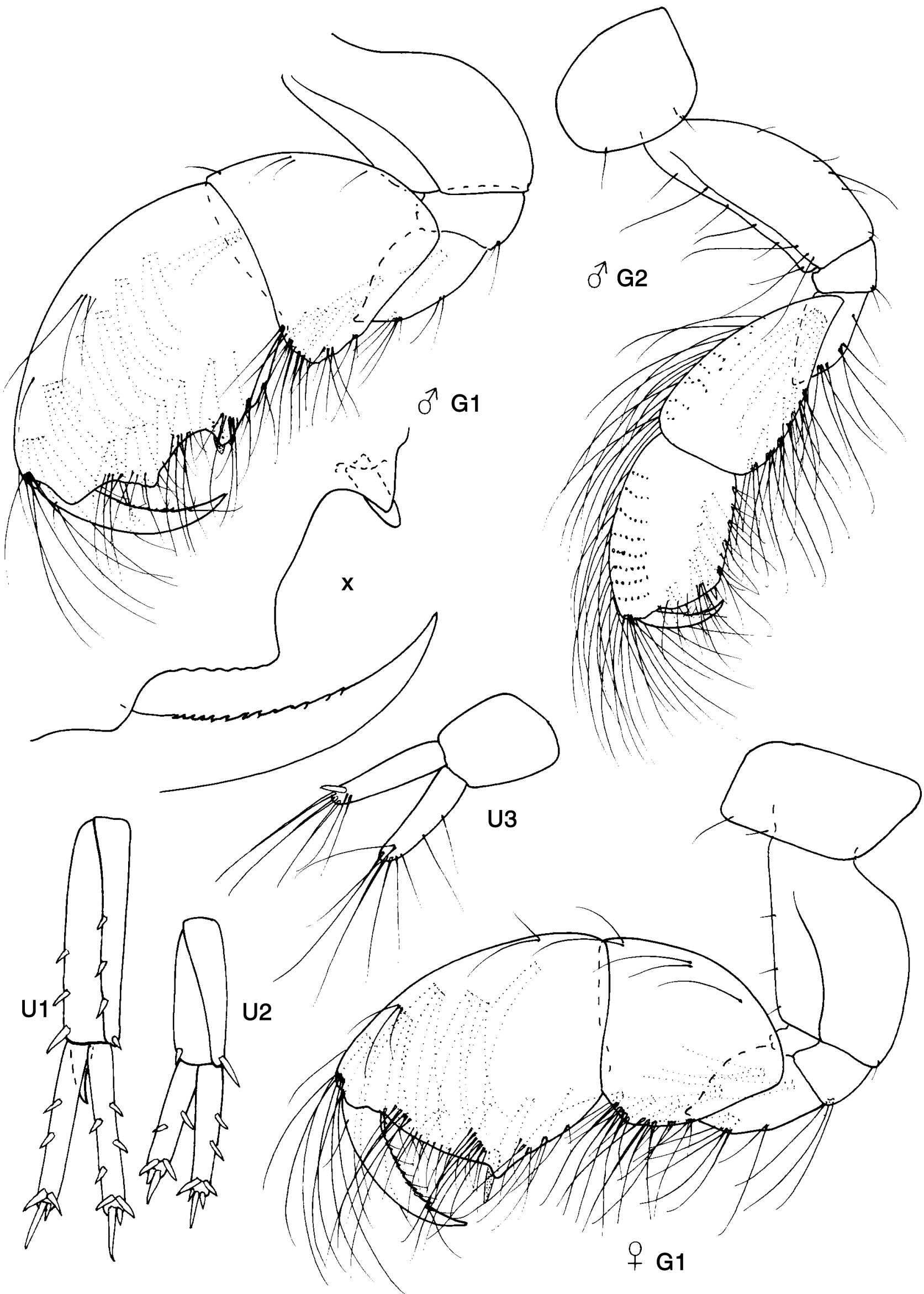

Fig. 3. Globosolembos rimatara n.sp., Rimatara, Austral Isles, male paratype; female paratype gnathopod 1. 


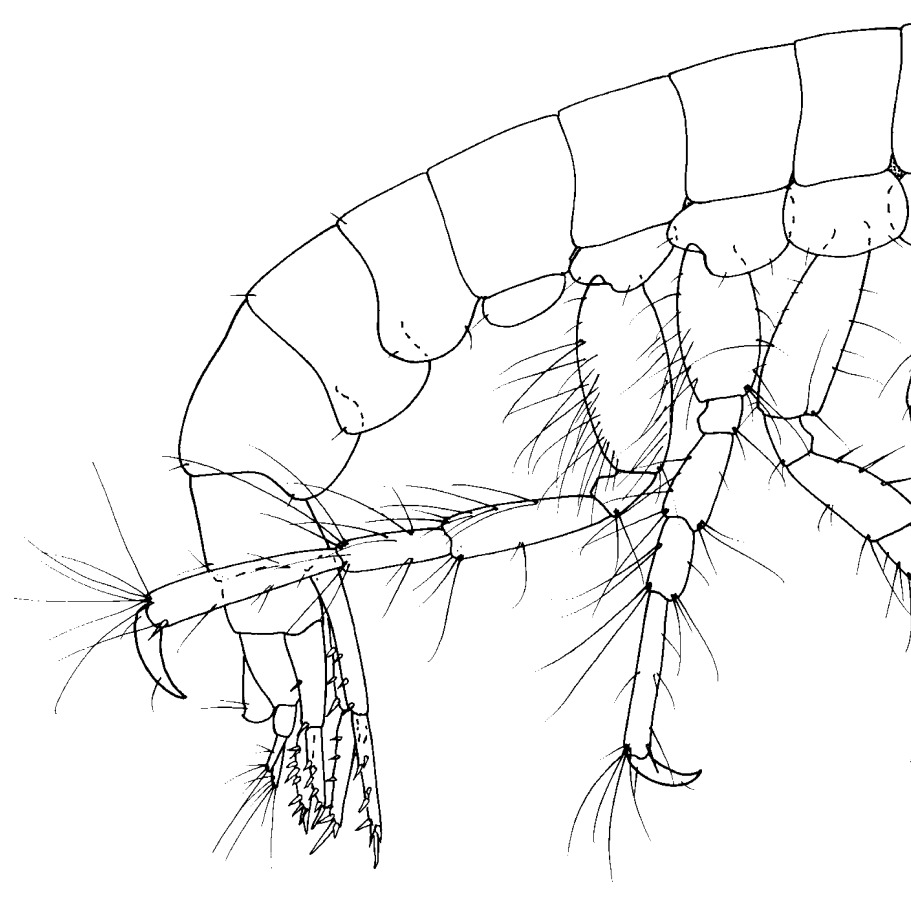

Fig. 4. Globosolembos rimatara n.sp., Rimatara, Austral Isles. male paratype.

\section{References}

Ledoyer, M., 1982. Crustacés Amphipodes gammariens Famille des Acanthonotozomatidae á Gammaridae. Faune de Madagascar 59(1): 1-598.

Ledoyer, M., 1984. Les Gammariens (Crustacea, Amphipoda) des herbiers de phanerogames marines de Nouvelle Caledonie (région de Noumea). Memoires du Museum nationale d'Histoire naturelle A, Zoologie 129: 1-113.

Myers, A.A., 1975. Studies on the genus Lembos Bate. III. IndoPacific species. L. kidoli sp. nov., L. ruffoi sp. nov., L. excavatus sp. nov., L. leptocheirus Walker. Bolletino del Museo Civico di Storia Naturale, Verona 2: 13-50.

Myers, A.A., 1985a. Studies on the genus Lembos Bate. XI. Globosolembos sub-gen. L. (G.) francanni Reid, L. (G.) indicus Ledoyer, L. (G.) ovatus sp. nov., L. (G.) tiafaui sp. nov., $L$. (G.) excavatus Myers. Bolletino del Museo Civico di Storia Naturale, Verona 10: 341-367.

Myers, A.A., 1985b. Studies on the genus Lembos Bate. XII. $L$. dentischium Myers ssp taparum nov., L. saloteae sp. nov., $L$. waipio Barnard, L. aequimanus Schellenberg, L. virgus sp. nov., L. regius sp. nov., L. tui sp. nov. Bolletino del Museo Civico di Storia Naturale, Verona 10: 369-406.

Myers, A.A., 1986. Amphipoda from the South Pacific: Tonga. Records of the Australian Museum 38: 271-289

Myers, A.A., 1988. The genera Archaeobemlos nov. gen. Bemlos Shoemaker, Protolembos Myers and Globosolembos Myers (Amphipoda, Aoridae, Aorinae) from Australia. Records of the Australian Museum 40(5-6): 265-332.

Myers, A.A., 1990. Amphipoda from the South Pacific: the Cook Islands. Records of the Australian Museum 42(2): 149-157.

Myers, A.A., 1995. The Amphipoda (Crustacea) of Madang Lagoon: Aoridae, Isaeidae, Ischyroceridae, and Neomegamphopidae. Records of the Australian Museum, Supplement 22: 22-95.

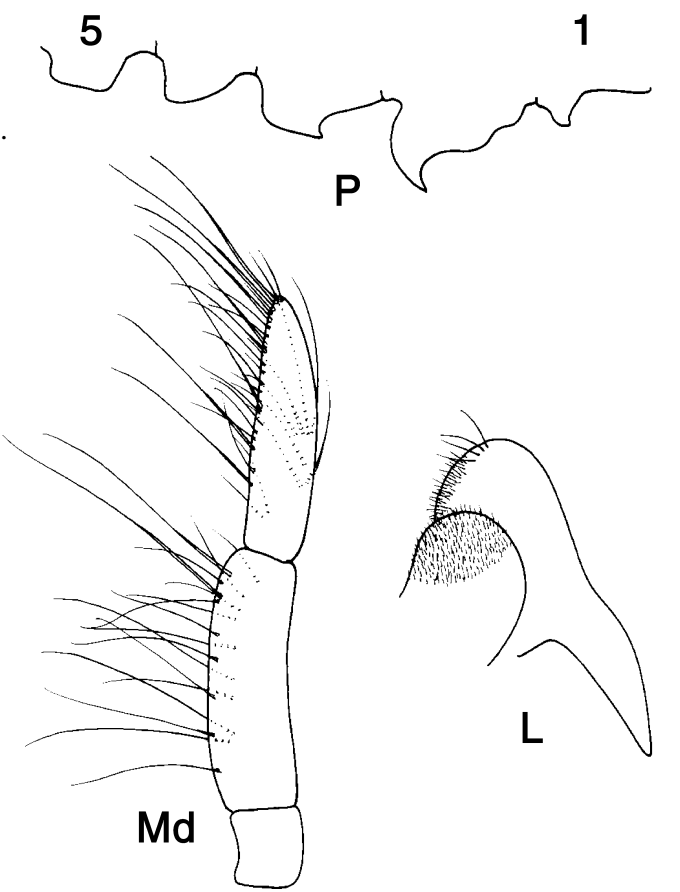

Myers, A.A., 1997. Amphipoda from the South Pacific: Western Samoa. Records of the Australian Museum 49(1): 99-109.

Myers, A.A., 1998. The Amphipoda (Crustacea) of New Caledonia: Aoridae. Records of the Australian Museum 50(2): 187-210.

Pirlot, J., 1938. Les amphipodes de l'expédition du Siboga. Deuxième partie: III(2): Dexaminidae-Podoceridae. Siboga Expéditie. Monographie 33f: 329-359.

Manuscript submitted 3 September 2001, revised 21 September 2004 and accepted 2 August 2005.

Associate Editor: G.D.F. Wilson. 